\title{
CENTRAL EFFECTS OF FIVE MUSCLE RELAXANTS*
}

\author{
Lewis W. Hersey, M.D., Charles W'. Gowdey, D.Phil., and \\ WolfGang SPOEREL, M.D., F.R.C.P.(C.) $\ddagger$
}

RESEARCH in the past twenty years has contributed significantly to the basic understanding and management of diverse problems in various aspects of clinical medicine. Not the least of these have been advances in anaesthetic techniques, equipment, and available agents which now make possible the contemplation and execution of surgery on "bad risk" patients under such deliberately altered conditions of body economy as hypothermia and extracorporeal circulation. Under such conditions the possibility then arises that the side-effects of a compound or group of compounds may have much more significance than previously.

The introduction of curare into clinical anaesthesia in 1942 by Griffith and Johnson $^{1}$ has led to a steadily increasing use of muscle relaxants. A voluminous literature has developed relating to their mode of action both clinically and in the laboratory, and a review of these agents in man has been recently prepared by Foldes. ${ }^{2}$

It is well accépted that some patients exhibit an abnormal response to relaxant administration, the most vexing and probably the most familiar being that of prolonged hy poventilation or apnoea. Having excluded such causes of respiratory failure as hyperventilation with suppression of the Hering-Breuer reflex, hypocarbia secondary to hyperventilation, gross hypoventilation with carbon dioxide narcosis, respiratory depression secondary to hypnotics, depleted plasma pseudocholinesterase, electrolyte imbalance, and obvious overdosage of relaxant with prolonged myoneural block, there remains a group in which no ready cause is apparent and where a direct central effect of relaxants might be considered.

The purpose of the present study was to assess the central activity of five muscle relaxants in healthy dogs under conditions which excluded all of the abovementioned factors.

\section{Method}

The investigation of the central action of drugs makes it necessary to separate the central from peripheral effects of the injected agent. To accomplish this, the classical isolated-head technique described by Heymans and Ladon ${ }^{3}$ and Heymans and Heymans ${ }^{4}$ was used. The method utilizes the cardiovascular system of one

*A preliminary report of this work was presented at the 1960 Fall Meeting of the American Society for Pharmacology and Experimental Therapeutics (Hersey, L. W., The Pharmacologist \&: 86 [1960]).

†Awarded British Oxygen Canada Prize 1961.

$\ddagger$ Departments of Pharmacology and Anaesthesia, Faculty of Medicine, University of Western Ontario, London, Canada.

Can. Anaes. Soc. J., vol. 8, no. 4, July, 1961 
dog (Donor) to perfuse the head of another (Recipient) which has been separated from its body except for its nervous connections (Fig. 1).

CROSS-CRCULATION DOGS

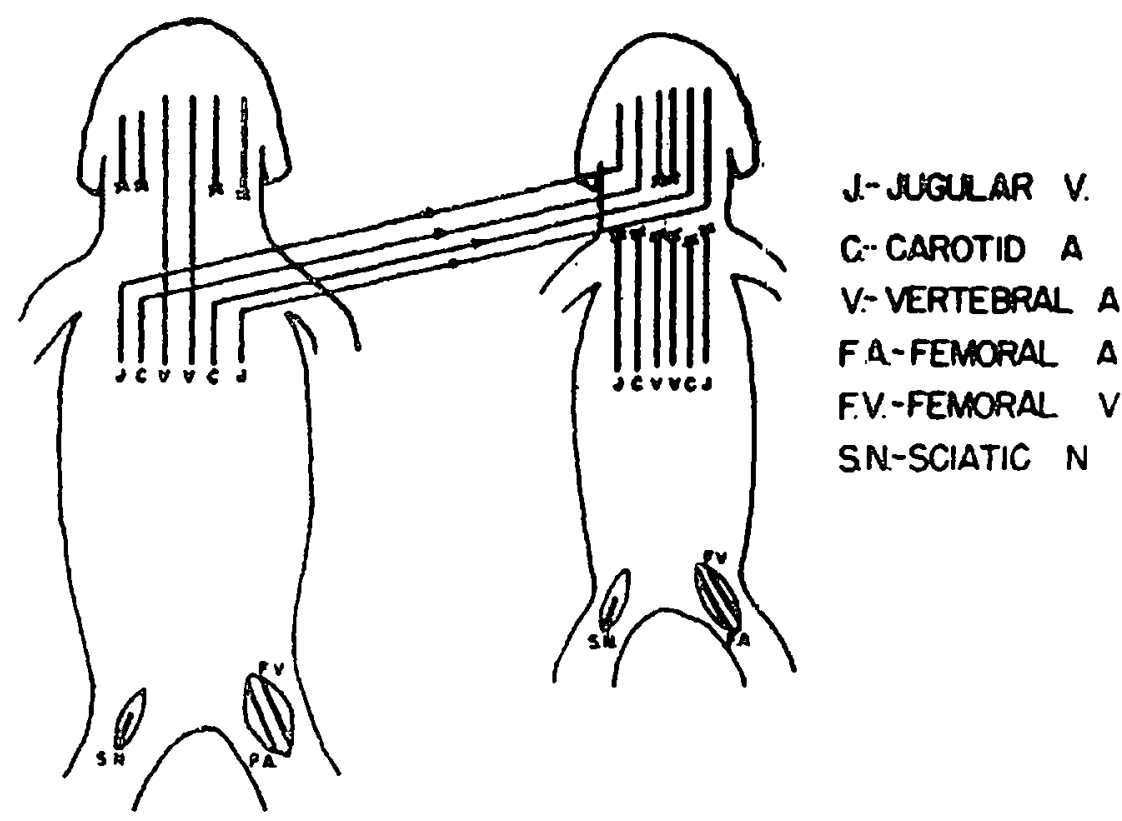

DONOR RECPIENT

FIGLRE 1

Healthy dogs of average weights of $15-20 \mathrm{~kg}$. were anaesthetized with intravenous pentobarbital sodium $30 \mathrm{mg} . / \mathrm{kg}$. and one femoral artery and vein were cannulated in each dog. The arterial blood pressure of each could then be continuously recorded on a kymograph. Tracheostomy was performed on each animal and a glass $T$-cannula was inserted into the donor, while in the recipient a special copper tracheal cannula for attachment of a Hall pneumotachygraph was inserted. The carotid arteries and external jugular veins were isolated in both dogs and, after the donor had received $5 \mathrm{mg} . / \mathrm{kg}$. Heparin intravenously, vascular anastomoses were established (as shown in Fig. 1) between the two dogs by means of siliconized plastic catheters fitted with capped side tubes for injections. Harvard Model 607 respirators were used when the respiratory rate and/or tidal volume decreased by an arbitrary 50 per cent of control values in either animal. Rectal temperature in each animal was recorded periodically with standard mercury thermometers. The electrocardiograph and electroencephalograph of each animal were recorded on a Grass Model 5 polygraph by means of four-limb subcutaneous plate electrodes and occipital and parietal needle electrodes respectively. The respiratory activity of the recipient, measured by the pneumotachygraph, was also recorded on the Grass polygraph. Then, one sciatic nerve in each animal was isolated and divided for subsequent electrical stimulation with bi-polar electrodes and a Grass square-wave stimulator.

The adequacy of circulatory isolation from the recipient body was checked before injection of the relaxant drugs by intravenous administration of $20-40$ $\mu \mathrm{gm}$. adrenaline into the femoral vein of the donor dog. A prompt pressor response 
in the donor and a reflex bradycardia and hypotension in the recipient was indicative of successful isolation. ${ }^{6}$ A similar injection after the series of relaxant injections was done in most cases to demonstrate the persistence of circulatory isolation during the experiment.

The relaxant drug was injected into one carotid-artery cross-over tube so that it went directly into the cerebral circulation of the recipient dog. The dose of relaxant was doubled at intervals of five minutes and continuous recordings of the arterial blood pressure, EEG; EKG, and respiratory activity were made. Interrupted shocks of 40 volts and 5-msec. duration were applied to the distal end of the sectioned sciatic nerve before and two minutes after each injection of relaxant to ascertain the presence or absence of myoneural block; this response was observed visually. A total of approximately ten times the myoneural blocking dose in the donor was given and effects on the abovementioned parameters were noted in the recipient. In three experiments arterial and venous blood samples were obtained from the cross-over tubing for oxygen determinations by the Roughton-Scholander method. ${ }^{5}$

The following relaxants were used, one agent being used in each experiment: succinylcholine chloride (Anectine ${ }^{\circledR}$, Burroughs Wellcome); d-tubocurare chloride (Tubarine ${ }^{\circledR}$, B.W.); decamethonium (Syncurine ${ }^{\circledR}$, B.W.); gallamine tri-ethiodide (Flaxedil ${ }^{\circledR}$, Poúlenc); 1,6-hexamethylene-bis-carbaminoylcholine (Imbretil ${ }^{\circledR}$, B.W.)

\section{RESL:LTS}

The present experiments revealed that, collectively, as indicated in: Table I, electrocardiograph activity was unimpaired in the absence of hypoxia. Arterial blood pressure in both donor and recipient was well maintained in every experiment at all the dosage levels employed, except for the d-tubocurare group. In the d-tubocurare group, a significant hypotension was observed' in each experiment and intravenous methoxamine or metamphetamine was given via the donor femoral vein to maintain perfusing pressures.

Two principal positive findings resulted from these experiments. First, in the experiments with decamethonium, curare, and hexamethylene bis-carbaminoylcholine (HMCC), signs of cerebral stimulation were elicited. With decamethonium both EEG and clinical evidence of convulsions following intra-arterial doses of 0.32 and $0.64 \mathrm{mg}$. $/ \mathrm{kg}$. were noted (Fig. 2) in two of the three experiments with this agent. In one experiment with curare, although no clinicad evidence of convulsions was observed, there was questionable EEG evidence of cerebral stimulation. Finally, in one of the four HMCC experiments there was EEG and clinical evidence of convulsive activity. In all of these experiments oxygenation and cerebral perfusion was felt to be adequate and in the HMCC experiment the arterial oxygen content at the time of convulsions was 17.6 volumes per cent. This finding excluded the possibility that hypoxia was the cause of deranged cerebral activity.

Secondly, respiratory depression was significant and marked in all experiments. This depression was shown to be independent of myoneural block. In each case there was respiratory depression of over 50 per cent in the recipient in the presence 


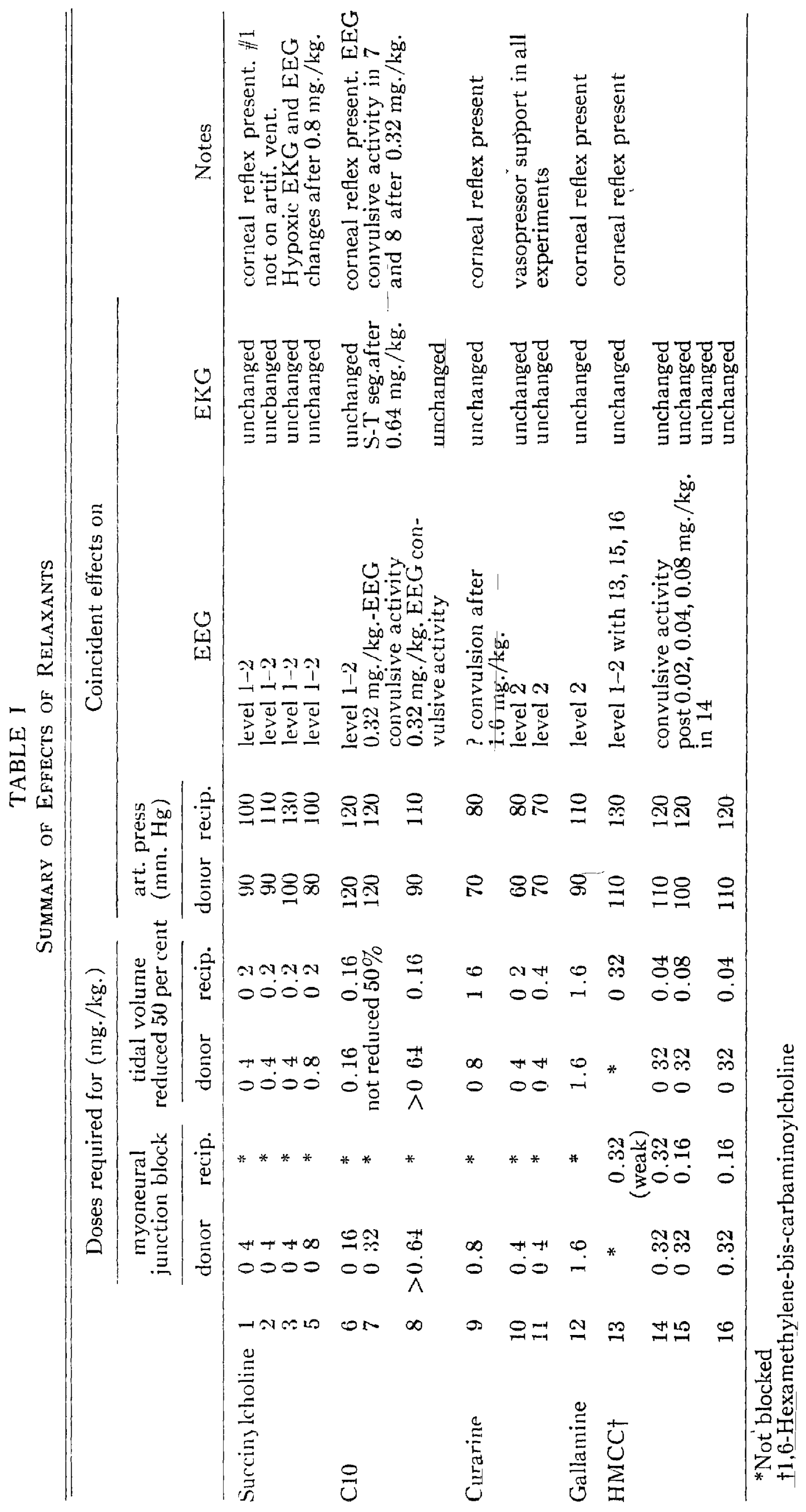




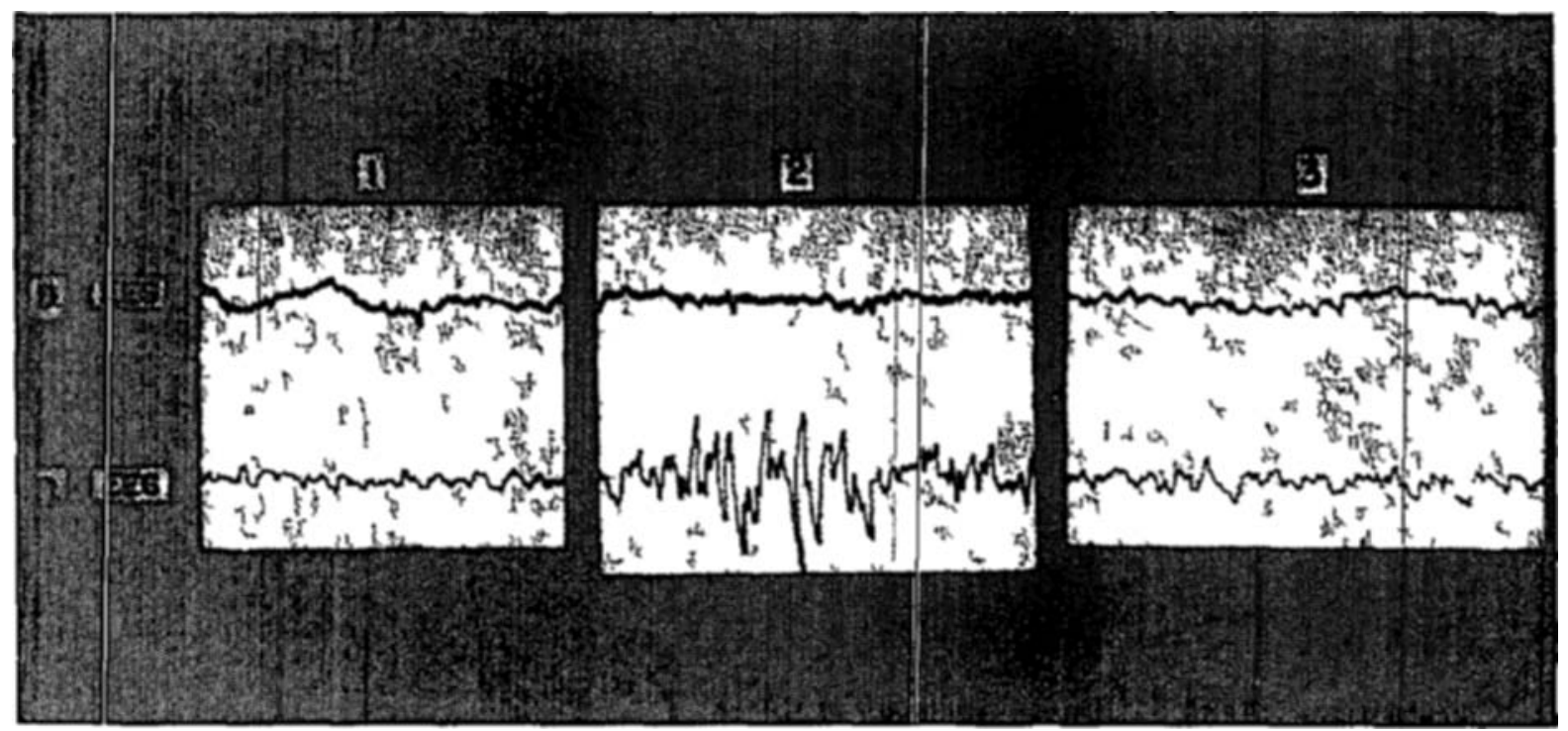

Tisure 2 Decamethonum-convulsions Panel 1 pre convulsions Panel 2 con vulsive activity in $\mathrm{R}$ post $032 \mathrm{mg} / \mathrm{kg}$ intracarotid injection Panel $330 \mathrm{sec}$ post convulsion noting some flattening and increased slow wave activity $10 \mathrm{~mm} / \mathrm{sec}$ (D Jonor $\mathrm{R}$ recipient)

of an int act myoneural junction. These effects and the doses required to produce them are summarized in Table II A typical tracing of respiratory depression is shown in Fig 3

TABLE II

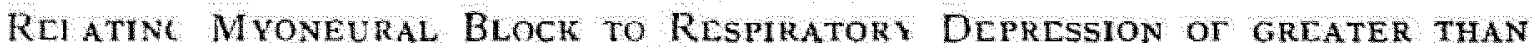
50 PER CCNT

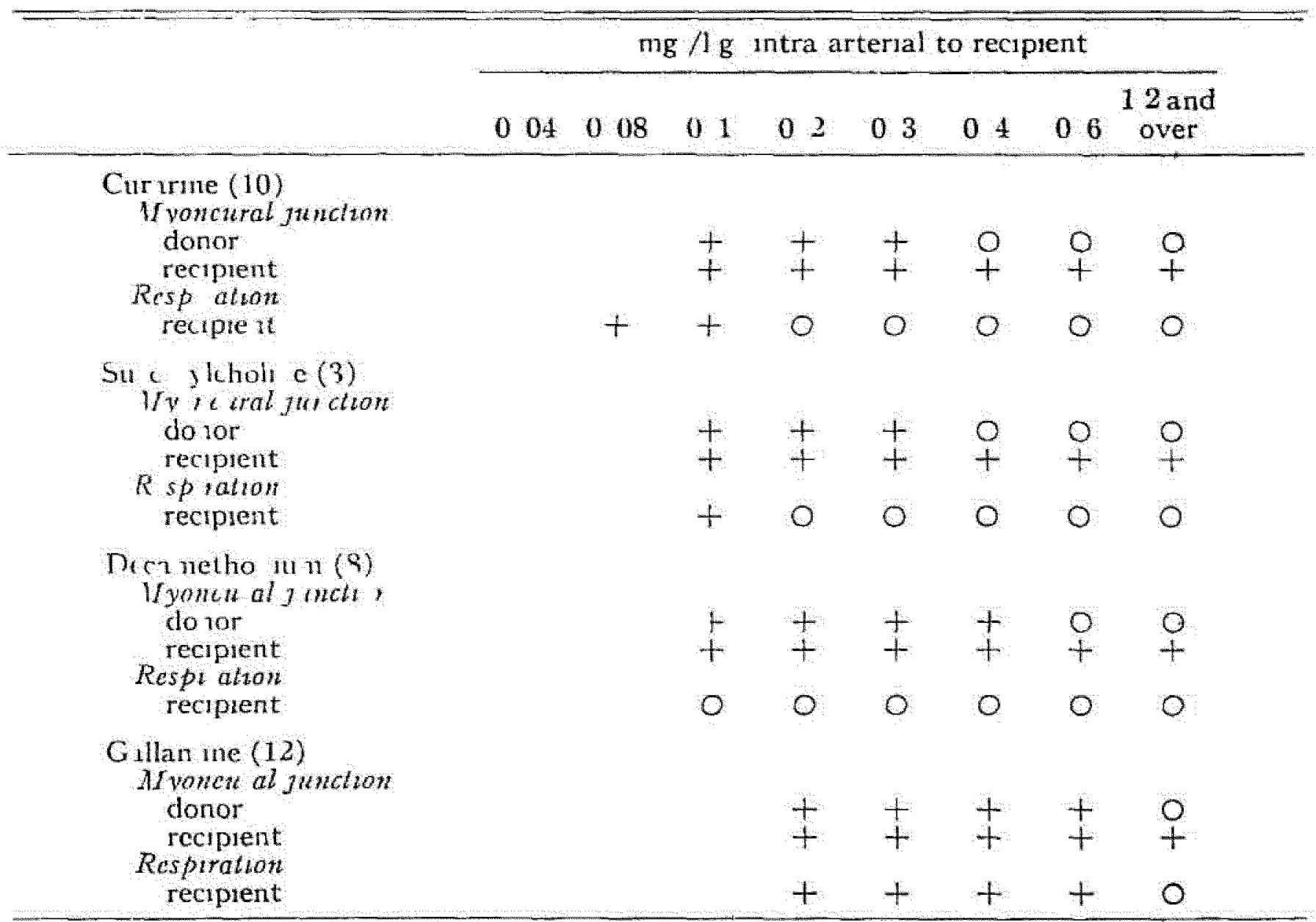

+ no blocked $O$ blocked 


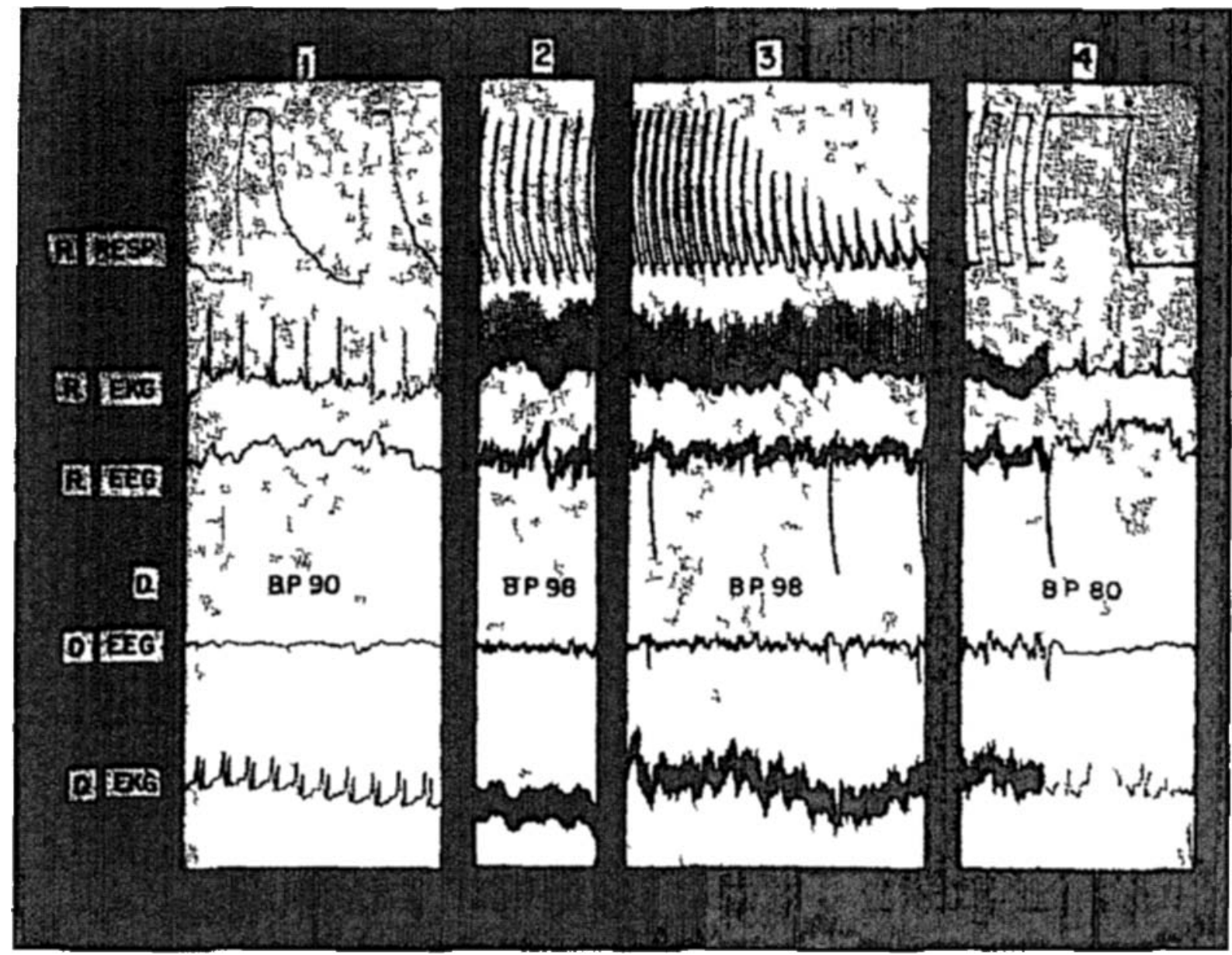

Figure 3 Decamethonium Panel 1 pre injection $25 \mathrm{~mm} / \mathrm{sec}$ Panel 2 pre injection $10 \mathrm{~mm} / \mathrm{sec}$ Panel 3 post $016 \mathrm{mg} / \mathrm{hg}$ intracarotid injectiol showt $\mathrm{sg}$ decline in $\mathrm{R}$ respiration Panel 4 post $064 \mathrm{ng} / \mathrm{kg}$ intracarotid yection at 10 $\mathrm{mm} / \mathrm{sec}$ and $25 \mathrm{~mm} / \mathrm{sec}$ showing lack of EKG and EEG effects (D do ior R recipient)

The four experiments with the new agent 16 Heximethy lenc bis carbaminoyl cholne (HMCC) deserve special mention in respect to both central effects on respiration and my oneural bloch There was a const int and very morhed decrease in both tidal volume and respiratory rate following $004 \mathrm{mg} \mathrm{hg}$ in three experi ments and following $032 \mathrm{mg} / \mathrm{hg}$ in the fourth (T $\mathrm{tble}$ I) There w 1 s no evidence of myoneural block in the donor dog until f fter $032 \mathrm{mg} / \mathrm{kg}$ in three experments and a block was never obtaned in the donor $n$ the fourth In exch of the HVCC experiments however evidence of nivoneural bloch was demonstrated in the recipient dog with the dosages shown in Tible I This did not occur in anv experiments with any of the other agents lthough they were conducted under the same conditions Table III which relites moneural bloch to respirators depression in a typical HMCC experment can be compared with Table II in which this same relationship is expressed with the four commonly used relaxints To investigate further the myoneural blocking effect of HMCC the classic experiment of Claude Bernard utihzing the frog sciatic nerve gastrocnemus preparztion was performed on four different fross using control frogs with d tubocurare Doses of $002 \mathrm{o} 012$ and $014 \mathrm{mg} / \mathrm{gm}$ HMCC were injected into the dorsal lymph sac but no myoneur al block was ever obtaned The control frogs received 015 and $032 \mathrm{mg} \mathrm{gm}$ d tubocurere which elicited a mvoneural 
TABLE III

Relating Mioneural Bloch to Respiratory Depression with HMCC*

\begin{tabular}{|c|c|c|c|c|c|c|c|c|c|c|}
\hline & \multicolumn{10}{|c|}{$\mathrm{mg} / \mathrm{hg}$ intra arterial to recipient } \\
\hline & 001 & 002 & 004 & 008 & 01 & 02 & 03 & 04 & 06 & 12 \\
\hline $\begin{array}{l}\text { Myoneural jtinction } \\
\text { donor } \\
\text { recipient }\end{array}$ & + & + & + & + & $\stackrel{+}{o}$ & $\stackrel{+}{0}$ & $\begin{array}{l}0 \\
0\end{array}$ & $\begin{array}{l}0 \\
0\end{array}$ & $\stackrel{\circ}{\circ}$ & \\
\hline $\begin{array}{l}\text { Respiration } \\
\text { recipient }\end{array}$ & + & + & $\underline{\mathrm{O}}$ & $\mathrm{O}$ & 0 & $\mathrm{O}$ & 0 & $\overline{0}$ & 0 & \\
\hline
\end{tabular}

*1 6 hexamethy lene bis carbuminoylcholine

+ not blocked $O$ blocked

block in the leg with intact blood supply, as might be expected On the other hand, in dogs the Claude Bernard experiment revealed that in the leg with occluded blood supply no bloch occurred, whereas in the limb with intact circu lation a block occurred This bloch occurred at the mroneural junction because it was shown that direct stimulation of the muscle elicited a response, and stimulation of the central end of the cut sciatic nerve produced a pressor response showning that the nerve could still conduct impulses Later studies demonstrated that intrathecal mjections of Imbretil were capable "of producing myoneural bloch in the perfused leg but agan occlusion prevented its action in the other leg Further experimental worh is in progress to elucidate this block

\section{Discussion}

The present study indicates that with each of the agents a very definite respiratory depressant effect can be elicited which is independent of peripheral noyneural block The findings of Harmel et al ${ }^{\top}$ in cross-circulation experiments llso showed a cuntral respiratory depression Cardiovascular effects were minmal except with d tubocurire which consistently caused hypotension with larger iloses

Previous work on the central effects of relaxants following the introduction of curare into clirik il andesthesia in 1942 has been largely inconclusive McIntyre ct $a l^{\text {s }}$ and Cllis $e t$ al ' 11 cxperiments with cats and dogs noted central depression following intravenous curare is evidenced by the EEG and by respiratory arrest Anoxic phenomena were not ruled out and Everett, ${ }^{10}$ in experiments on cats, ribbits and rats felt that d tubocurare had little central effect per se, but that if anoxia developed then convulsions occuried Salama and Wright ${ }^{11}$ demonstrated that direct application of curare to the exposed cortex or via subarachnoid injection resulted in stumulation of vasomotor, respiratory, cardiac, and other autonomic centres, but igan the adequacy of cerebral oxygenation was not clarified McIntyre $e t$ al ' concluded that the conflicting results were due in part to dosage and mode of application The evidence to that time suggested that d tubocurare uas capable of modifying central nervous system activity independent of secondary anoxic effects " 1411 It does not follow that non-curarizing dosages are devoid of all central action and the present experiments with d tubocupure indicate a definite central effert respiratory depression or apnoea was 
produced repeatedly in the presence of an intact myoneural junction in the recipient animal.

Haber et al. ${ }^{15}$ in their investigation of the site of the inspiratory and expiratory centres in the medulla using microelectrodes found no evidence of central depression of respiratory discharges following succinylcholine up to fifty times the paralyzing dose, or with d-tubocurare and decamethonium. Similarly, Paton and Zaimis ${ }^{16}$ found no change in phrenic-nerve action potentials following d-tubocurare and decamethonium in paralyzing doses until asphyxia supervened, at which time discharges were intensified. These findings are at variance with the results of our study and with those of Harmel t $_{\text {al. }}{ }^{7}$

In the present experiments it appears that the muscle relaxant agents are indeed able to depress respiratory activity when in jected directly in to the cerebral circulation. This has been shown with each experiment, when respiratory activity was depressed significantly in the presence of an intact myoneural junction. We believe, also, that these experiments indicate that decamethonium in particular and, to a lesser extent, curare and HMCC are able to evoke cerebral stimulation when injected under the previously described conditions.

The manner in which the agent in question reaches its target - in this case the central nervous system-inevitably evokes the blood-brain or blood-tissue barrier. By intra-arterial injections the cerebral circulation could be selectively perfused with the agent unaltered by metabolic processes.

In view of the apparent central effects discussed, the factors which are thought to influence blood-brain or blood-tissue permeability must be briefly considered. Paton $^{17}$ says the literature relevant to clinical work is unsatisfactory. Several workers-Paton, ${ }^{17}$ Foster, ${ }^{18}$ and Hunter ${ }^{19}$ - cite electrolyte derangements, particularly decreased potassium ion concentration, as contributing to increased permeability of the blood-brain barrier and consequent abnormal effects following administration of relaxants.

Cole $^{20}$ and Comroe and Dripps ${ }^{21}$ mention histamine release which is manifested in man by skin flushing (vasodilatation), hypotension, and bronchospasm, and in dogs by gastrointestinal haemorrhages. It is interesting to speculate whether widespread changes in tissue permeability, including the blood-brain barrier, may follow vascular injections of relaxants-all of which have been shown to exhibit histamine-releasing activity ${ }^{22}$-although in one study Paton and Zaimis ${ }^{16}$ found no evidence of histamine release following curare injection. Payne ${ }^{23}$ cites cases of transient gallamine-induced hypotension of $20-100 \mathrm{~mm}$. mercury following non-myoneural blocking doses and, noting that the hypotension was relieved by atropine, concluded that the mechanism was not central. Biological variation and the stimuli required to provoke histamine release from the perivascular or skin mast cells ${ }^{24}$ are obviously significant.

Besides the mechanisms of electrolyte imbalance and histamine as they affect tissue permeability in general and the blood-brain barrier in particular, there are two other factors which have been considered. The first is the effect of elevated carbon dioxide levels which was found in a study by Payne ${ }^{25}$ to oppose the action of succinylcholine, decamethonium, and gallamine, and to $\epsilon$ nhance the action of d-tubocurare. Concomitant studies of plasma potassium ion concentration and 
blood $\mathrm{pH}$ showed no direct relationship between plasma potassium and relaxant action. Payne suggests that changes in the degree of ionization and protein binding are responsible for changes in the permeability of the blood-brain barrier rather than hypercarbia per se. It is to be noted that in the present study hypoventilation and hypercarbia were avoided. The second factor is that of muscle temperature as it affects muscle relaxant activity. Bigland et al. ${ }^{26}$ reported that decreased muscle temperature increased the magnitude of the effect of depolarizing agents and prolonged their action, whereas cooling reduced the magnitude and duration of non-depolarization block. The effects of total body cooling have quite recently become of much greater clinical significance with the increased scope and extent of cardiovascular and neurosurgery and with wider use of the extracorporeal circulation.

Another variable in studies of this kind is that of species resistance; the classical experiment by Smith et al. ${ }^{27}$ is an example. The author himself was the experimental subject and received up to two and one-half times the paralyzing dose of d-tubocurare with no demonstrable central effects.

The new agent, Imbretil, was found to exhibit some interesting features in the experimental animal not found with the other agents. The observation that a peripheral block occurred in the limbs of the recipient despite the demonstration of circulatory isolation betweer the donor and the recipient's body was puzzling. Possibly there is a very marked permeability of the blood-brain barrier induced by hexamethylene carbaminoylcholine (HMCC)---to such an extent that in the recipient a significant amount reaches the isolated body via drainage from the spinal veins and causes a myoneural block without causing a similar block in the donor. The classical Claude Bernard experiment on dogs discussed earlier demonstrates the effect to be at the myoneural junction; it was also found that blockade could be induced by intrathecal injection of the Imbretil without any being administered directly into the circulation. There have been a number of clinical reports on the use of HMCC (Imbretil), the consensus being that a "dual block" was involved - with an initial depolarizing type being followed by a longer-acting non-depolarizing block which could be antagonized by neostigmine. ${ }^{28.29 .30}$ Reis $^{31}$ observed that ganglionic blocking agents tended to potentiate the myoneural block. Dripps ${ }^{32}$ remarked on the variable and unpredictable duration of respiratory depression and the lack of a reliable antagonist to this depression. These clinical studies on the unpredictability of blockade together with the excellent abdominal relaxation "almost equivalent to that obtained with spinal anaesthesia" 32 taken with the results of the present study would tend to support the concept of a high degree of permeability of the central nervous system to this agent and a not insignificant central effect per se. Certainly, further work is indicated in this field and further experimental investigation is contemplated.

\section{SummaRY}

Fifteen experiments utilizing cross-circulated healthy dogs were performed to investigate the purely central action of succinylcholine chloride, decamethonium, d-tubocurarine chloride, gallamine tri-ethiodide, and 1,6-hexamethylene-biscarbaminoylcholine bromide. 
The experiments were conducted under conditions of normothermia and controlled oxygenation and perfusion pressure to reduce the variables influencing the central nervous system.

All the relaxant drugs used were considered to exhibit central activity, apart from their well-known activity at the myoneural junction. Hexamethylene carbaminoylcholine, in particular, appeared to exert a marked central action because of its ability to permeate the blood-brain barrier with relative ease.

By far the most significant central effect was on the respiratory centre, causing depression and apnoea in the isolated recipient body. The dosage required to produce central respiratory arreșt or depression was found to approximate closely that required to produce a peripheral myoneural block in the donor body.

Significant tachyphylaxis was observed only with decamethonium, where it was difficult to effect myoneural block and long-lasting central respiratory depression.

Vasomotor effects were not noted except with d-tubocurare: increasing doses resulted in increasing hypotension.

Cerebral stimulation was elicited in two of the three decamethonium experiments, one of three curare experiments, and one of four hexamethylene carbaminoylcholine experiments.

No cardiac effects attributable to these agents were noted. A hypothesis for the possible action of hexamethylene carbaminoylcholine is suggested in the light of the results obtained in these experiments and from other published clinical reports. Further work in this field is indicated.

The increasing significance of altered body economy and the increased scope and extent of surgery in the presence of such conditions suggest to us that the side-effects of muscle relaxants may come to assume a more significant role than previously.

Species variation in the effects of myoneural blocking agents undoubtedly occurs, but it is felt that the present study, combined with the clinical appraisals, leads to the belief that central activity can indeed be significant in certain cases.

The nebulous blood-brain barrier offers a wide field for further investigation of drug action.

\section{ACKNOWLEDGMENTS}

This study was supported in part by a grant from Burroughs Wellcome and Company, Montreal, Canada; we wish to thank Dr. J. R. Bogert, Medical Director, for his interest in this problem. We are ipdebted to Dr. Roland Lee and Mr. James Boyd of the Department of Pharmacology, University of Western Ontario, for invaluable technical assistance, and to Dr. H. B. Graves, Director, Department of Anaesthesiology, Vancouver General Hospital, Vancouver, Canada, who aided in the final drafting of this manuscript.

\section{RÉSUMÉ}

Nous avons fait quinze expériences en employant des chiens en bonne santé en circulation croisée, pour étudier exclusivement l'action centrale du chlorure du succinylcholine, du décaméthonium, du chlorure de d-tubocurarine, du tri- 
iodure de gallamine et du bromure 1, 6-hexaméthylène-biscarbaminoyl-cholines.

Ces expériences ont été faites en maintenant la température normale mais en contrôlant l'oxygénation et la pression de perfusion dans le but de diminuer le nombre de facteurs susceptibles d'influencer le système nerveux central.

Tous les médicaments myorésolutifs nous ont semblé produire une activité centrale en plus de leur action bien connue à la jonction myoneurale. L'hexaméthylène carbominoylcholine en particulier a semblé produire une action centrale marquée à cause de sa facilité à traverser la barrière sang-cerveau.

L'action, de beaucoup la plus marquée sur le système nerveux central, s'est manifestée sur le centre respiratoire en provoquant une dépression et une apnée sur le récepteur isolé. La dose nécessaire pour provoquer un arrêt respiratoire central ou une dépression semble être voisine de la dose requise pour produire un blocage myoneural périphérique chez le donneur.

Une tachyphylaxie importante a été observée seulement avec le décaméthonium avec lequel il a été difficile de produire un blocage myoneural et une dépression respiratoire centrale d'une certaine durée.

Nous n'avons pas observé d'effets vaso-moteurs si ce n'est avec le d-tubo dont des doses croissantes ont provoqué une hypotension proportionnelle.

Une stimulation cérébrale a été manifeste au cours de deux des trois expériences avec le décaméthonium au cour's d'une des trois expériences avec le curare, et au cours d'une des quatre expériences avec l'hexaméthylène carbominoylcholine.

Nous n'avons olservé aucun effet de ces médicaments sur le cœur. A la suite des travaux publiéł sur ce sujet et des renseignements recueillis au cours de ces expériences, nous ènettons l'hypothèse d'une action possible sur le cœur de l'hexaméthylène carbominoylcholine. Il s'impose de continuer la recherche dans ce domaine.

L'importance croissante que prennent les perturbations organiques et l'extension progressive de la chirurgie dans ces circonstances nous portent à croire que les effets secondaires des myorésolutifs peuvent venir à jouer un rôle plus important qu'ils ne l'ont fait antérieurement.

Sans doute, il existe des variantes dues à l'espèce dans les effets du blocage myoneural, mais nous avons l'impression que l'étude actuelle, en plus de l'évaluation clinique, conduit à la conclusion que l'activité centrale, en certains cas, peut être assez marqueé.

Cette vague barrière sang-cerveau ouvre un champ considérable de recherches sur l'action des médicaments.

\section{REFERENCES}

1. Griffith, H. R., \& Johnson, G. E. Use of Curare in General Anaesthesia. Anesthesiology S: $418(1942)$.

2. Foldes, F. F. The Pharmacology of Neuromuscular Bloching Agents in Man. Clin. Pharm. \& Therap. 1: 345 (1960).

3. Heymans, C., \& Ladon, A. Recherches Physiologiques et Pharmacologiques sur la tête isolée et le centre vague du chien. Arch. Int. Pharmacodynam. 30:415 (1925).

4. Heymans, J. F., \& Heymans, C. Recherches Physiologiques et Pharmacodynamiques sur la tête isolée du thien. Arch. Int. Pharmacodynam. $92: 9$ (1926).

5. 'Roughton, F. J. W., \& Scholander, T. F. Microgusometric Estimation of Blood Gases. I. Oxygen J. Biol. Chem. 148: 541 (1943). 
6. Hevmans, C., \& Neil, E., Refloxegenic Areas of the Cardiovascular System. London: Churchill (1958).

7. HARMEL, M. H., KING, B. D., \& KAO, F. F. Dual Action of Succinylcholine on Respiration in Cross-circulated Dogs. J. Pharmacol. \& Exp. Therap. 124: 333 (1958).

8. McIntyre, Dunn A. L., \& Tullar, P. E. Effect of D-tubo curare on Electrical Activity of Dog's Brain. Fed. Proc. 5: 67 (1946).

9. Ellis, C. H., Morgan, W. V., \& deBeer, E. J. , Central Depressant Action of Certain Myoneural Blocking Agents. J. Pharmacol. \& Exp. Therapy. 106: 353 (1952).

10. Everett, G. M. Effects of D-tubo curare on Central Nervous System. Fed. Proc. 6: 101 (1947).

11. Salama, S., \& Wright, S. Action of D-tubo curare on CNS of Cat. Brit. J. Pharmacol. $5: 49$ (1950).

12. Mcintyre, A. R., Bennetr, A. L., \& Hamilon, C. Recent Advances in Pharmacology of Curare. Ann. N. Y. Acad. Sc. 54: 301 (1951).

13. Ostow, M., \& Garcia, F. Effect of Curare on Cortical Responses Evoked by Afferent Stimulation. J. Neurophysiol. 12: 225 (1949).

14. Cohnberg, R. E. Stimulation of CNS by Curare (Introcostrin). J. Lab. Clin. Med. 31: 866 (1946).

15. Haber, E.; Kohn, K.; NGai, S. H.; Holaday, D. A.; \& Wang, S. C. Location of Spontaneous Respiratory Neuronal Activities in Medulla of Cat: A New Location of Expiratory Center. Am. J. Physiol. 190: 350 (1957).

16. Paton, W. D. M., \& Zaimis, E. J. Action of D-tubo curare, Decamethonium on Respiratory and Other Muscles of Cat. J. Physiol. 112: 311 (1951).

17. Paton, W. D. M. Possible Causes of Prolonged Apnoca. Anaesthesia 19: 253 (1958).

18. Foster, P. A. Potassium Depletion and Central Action of Curare. Brit. J. Anaesth. 28: 488 (1956).

19. Hunter, A. R. Neostigmin-Resistant Curarization. Brit. Med. J. ii: 919 (1956).

20. Cole, F. A New Lethal Dose of Curare, with Some Observations on Pathology Produced by Large Doses. Anesthesiology $7: 190$ (1946).

21. Comroe, J. H., \& DripPS, R. D. Histamine-like Action of Curare and Tubocurarine Injected Intra-arterially in Man. Anesthesiology $7: 260$ (1946).

22. Foldes, F. F. Muscle Relaxants in Anesthesiology. Springfield: C. C. Thomas (1957).

23. Payne, J. P. Transient Hypotension in Cat Induced by Gallamine. Brit. J. Anaesth. 32: 7 (1960).

24. Paton, W. D. M. Effects of Muscle Relaxants Other than Relaxation. Anesthesiology 20: 453 (1959).

25. Payne, J. P. Influence of Carbon Dioxide on Neuromuscular Blocking Activity of Relaxant Drugs in Cat. Brit. J. Anaesth. 30: 206 (1958).

26. Bigland, B.; Goetze, B.; Maclagan, J.; \& Zaimis, E. J. Effect of Lowered Muscle Temperature on Action of Neuromuscular Blocking Drugs. J. Physiol. 141: 425 (1958).

27. Smith, S. M.; Brown, H. O.; Toman, J. E. P.; \& Goodman, L. S. Lack of Cerebral Effects of D-tubo curare. Anesthesiology 8:1 (1947).

28. Herzfelt, E., Kraupp, O., \& Stumpf, C. Der Anaesthesist 4: 171 (1955).

29. Mayrhofer, O. Zur Frage der Antagonisierbarkeit des longwirkenden, depolarisierenden muskel Relaxans Imbretil. Der Anaesthesist 4: 174 (1955).

30. Bergman, H. Spirographic Studies on the Method of Administration and Reversibility of the Synthetic Muscle Relaxant Hexamethylene-bis-carbamoylcholine (Imbretil). Der Anaesthesist 7: 137 (1958).

31. ReIs, H. Hexamethylene-bis-carbamoylcholine (Imbretil) als Basisrelaxans. Der Anaesthesist 4: 10 (1955).

32. Dripps, R. D.; Hanks, E. C.; Ngai, S. H.; Oech, S. R.; Papper, E. M.; \& Sechzer, P. H. A Clinical Study of the Muscle Relaxant Imbretil. Anaesthesiology 20:646 (1959). 